\title{
"WITH THE FIRST GRASS-BLADE": WHITMAN'S INFLUENCE ON THE POETRY OF CHARLOTTE PERKINS GILMAN
}

\author{
DENISE D. KNIGHT
}

On April 5, 1883, twenty-Two-Year-old Charlotte Perkins made the following entry in her private journal: "[G]o to Grace Channing's [house]. Mr. [William] O'Connor had left for me a beautiful new copy of Leaves of Grass. Walt Whitman is an intimate friend of his. I am obliged to decline [however], as I had promised Walter I would not read it." For his part, Perkins' fiancé, Walter Stetson, also recorded the incident in his diary and made clear his reasons for forbidding Charlotte to read Whitman's poetry. "I did not want her to think all men such animals as Whitman described them,"2 he wrote solemnly. In spite of the youthful pledge made to her husband-to-be, however, Gilman did go on to read Whitman, to praise his poetry, and to emulate his style in her own highly acclaimed edition of verse, In This Our World, first published in 1893.

Although best known for her haunting short story, "The Yellow Wall-Paper," Charlotte Perkins Gilman (1860-1935) was also an accomplished poet who wrote and published nearly five hundred poems, many of which reflect the influence of Whitman's verse. Shortly after her formal separation from Walter Stetson in 1891, Gilman publicly hailed Whitman as "America's greatest poet" 3 and wrote various diary entries which revealed her deep and abiding admiration of his verse.

It was his sympathy with women that first attracted Charlotte Perkins Stetson to Whitman's poetry. Regarded by poet Karl Shapiro as "the first great American feminist," Walt Whitman recognized in his verse the desire for women to be released from the bondage of socially prescribed roles. That impulse for freedom-sexual, physical, spiritual-is seen in Whitman's expressive style and in his imagery. As Mabel McCoy Irwin pointed out in her 1905 defense of Whitman's verse, his poetic depictions of women-his "songs of woman's deliverance" - illuminated the potential of his largely female audience: "He flashed upon her transcendent light, that she might discover her own greatness," Irwin wrote. ${ }^{5}$ Indeed, Whitman seemed to speak to the very soul of Charlotte Perkins Stetson, encouraging the discovery and nurturance of her own emerging poetic voice. So strong and lasting, in 
fact, was Whitman's influence, that during a two-year extended lecture tour, when she had no permanent address to call "home," Gilman included among her travel "necessities" just two books: Olive Schreiner's Dreams and Whitman's Leaves of Grass. ${ }^{6}$

Whitman's influence on Gilman's poetic endeavors was significant. ${ }^{7}$ Like Whitman, Gilman routinely added and deleted poems to her own collections of verse, revised them, and restructured the sequence of her selections in subsequent editions. Significantly, in the third printing of her third and final edition of In This Our World (1908), Gilman opened with a celebratory poem titled "Birth," which is clearly reminiscent of one of the major thematic emphases of "Song of Myself." She begins the poem:

Lord, I am born!

I have built me a body

Whose ways are all open

Whose currents run free

From the life that is thine

Flowing ever within me,

To the life that is mine

Flowing outward through me. ${ }^{8}$

Like Whitman, Gilman, in this opening stanza, celebrates the transcendent nature of the "self " in various ways: in relation to the external world, in relation to others, and in relation to the spiritual world. Moreover, the woman poet conveys a solid sense of confidence in terms of who and what she has become-a woman reborn, embracing middle age with a renewed love of life and a spirit of adventure. Gone are the inhibitions of earlier years: the apprehension, the insecurity, the wounded psyche bearing the scars of a nervous breakdown at the age of twenty-six. In fact, "Birth" was written as Gilman entered one of the most productive phases of her long career, during which she would singlehandedly write, edit, and publish the socialist/feminist magazine, The Forerunner, which appeared from 1909 to 1916.

Despite Gilman's emphasis on new-found freedom and her experimentation with provocatively sensual imagery, her verse stops short of incorporating the kind of bold sexual allusions that Walter Stetson found so objectionable in his prudish indictment of Whitman's "animalism." But although "Birth" avoids explicit representations of sexuality, Gilman's subtle allusions to her body, to its texture and color, to spiritual union, to birth, and to free-running currents, all suggest an implicit endorsement of Whitman's uninhibited celebration of the body and soul. The poem continues: 
I am clothed, and my raiment

Fits smooth to the spirit,

The soul moves unhindered,

The body is free;

And the thought that my body

Falls short of expressing,

In texture and color

Unfoldeth on me. . . .

Lord, I am born!

From inmost to outmost

The ways are all open,

The currents run free,

From thy voice in my soul

To my joy in the people-

I thank thee, O God,

For this body thou gavest,

Which enfoldeth the earth-

Is enfolded by thee! (ITOW, 2)

In its entirety, "Birth" can be read not only as a celebration of Gilman's newly evolved self, but also as a posthumous tribute to Whitman, who died while Gilman was in the process of compiling her first edition of poetry. While Walter Stetson had chided his young bride for being "too affectionately expressive," Whitman's verse captured the freedom of experience that Charlotte seemed to crave. Caressed by his feminine sensibilities, seduced by his bold eroticism, and captivated by his call for democracy, Charlotte Stetson found in Walt Whitman a kindred spirit. While Whitman was criticized and condemned for his bold depictions of sexuality-both male and female-Charlotte Stetson was similarly attacked for her unconventional views about women's roles and responsibilities. Not only did she find his poems inspirational and sensitive, but reading them was also an act of defiance against her young husband who found Whitman's verse to be distasteful and impure. Walter Stetson's journal attack against Whitman continued: "I wanted [Charlotte] to find love and the sexual relations something so holy and lovely that it goes into some hidden place to enjoy its holiness rather than stands in the market places and cries up the odor of its perspiration, the action of its phallus, the hairiness of sweating breastsand all the Whitman delicacies. . . The world might call me prurient and evilminded, but I object to Whitman, wholly" (Endure, 201-202). Charlotte Stetson's acquiescence to her husband's objections, however, was only temporary. Not only did Gilman frequently quote from Whitman during her speaking engagements in the 1890s, but her ambitious experiment with free verse began after her separation from Walter Stetson.

Inspired, too, by Whitman's invigorating celebrations of life and death, Gilman wrote several individual poems which betray the extent of 
Whitman's influence. Perhaps the best of Gilman's spiritual poems is one titled "Among the Gods." The poem describes the speaker's contemplation of the universe as she transcends earth and moves toward heaven. Concurrent with the speaker's steady ascension is an enhancement of both her visual acuity and her spiritual awareness as she discovers the god within and around her. The poem reads, in part:

How close the air of valleys, and how close

The teeming little life that harbors there!

For me, I will climb mountains. Up and up,

Higher and higher, till I pant for breath

In that thin clearness. Still? There is no sound

Nor memory of sound upon these heights.

Ah! the great sunlight! The caressing sky,

The beauty, and the stillness, and the peace!

Blessed these heights of freedom, wisdom, rest!

I will go higher yet. . . .

Alone, triumphant, man above the world,

I stand among these white eternities. . . .

I reign supreme.

And in this utter stillness and wide peace

Look calmly down upon the universe.

Surely that crest has changed! That pile of cloud

That covers half the sky, waves like a robe!

That large and gentle wind

Is like the passing of a presence here!

See how yon massive mist-enshrouded peak

Is like the shape of an unmeasured foot,-

The figure with the stars!

$\mathrm{Ah}$ ! what is this? It moves, lifts, bends, is gone!

With what a shocking sense of littleness-

A reeling universe that changes place,

And falls to new relation over me-

I feel the unseen presence of the gods! (ITOW, 67-69)

Like Whitman throughout much of "Song of Myself," Gilman's speaker views death as simply another stage of existence, rather than an experience to be feared. Whitman writes, "All goes onward and outward, nothing collapses, / And to die is different from what any one supposed, and luckier."10 Gilman's speaker echoes those sentiments as she calmly and peacefully assesses her surroundings.

In the poem titled "Desire," Gilman responded to Whitman's command in Section 2 of "Song of Myself," to "no longer take things at second or third hand, nor look through the eyes of the dead" $(L G, 30)$. Through the exercise of her imagination, Gilman's speaker experiences the transcendence of the self and its immersion in nature. Like Whitman's speaker in Section 33 of "Song of Myself," Gilman's speaker seems to be going "afoot with [her] vision" $(L G, 61)$. She also invokes Whitman's blade of grass imagery, which recurs in several of her poems: 
With the first grass-blade, I desire the sun;

With every bird that breathes, I love the air;

With fishes, joy in water; with my horse,

Exult in motion; with all living flesh,

Long for sweet food and warmth and mate and young;

With the whole rising tide of that which is,

Thirst for advancement, - crave and yearn for it!

Yea, I desire! Then the compelling will

Urges to action to attain desire.

What action? What desire? Am I a plant,

Rooted and helpless, following the light

Without volition? Or am I a beast,

Led by desire into the hunter's snare?

Am I a savage, swayed by every wish,

Brutal and feeble, a ferocious child?

Stand back, Desire, and put your plea in words.

No wordless wailing for the summer moon,

No Gilpin race on some strong appetite,

Stand here before the King, and make your plea.

If Reason sees it just, you have your wish;

If not, your wish is vain, plead as you will.

The court is open, beggar! I am King! (ITOW, 34-35)

The imaginative juxtaposition of fragile plant imagery with that of an unrestrained beast recalls again Gilman's actual, as well as her symbolic, evolution from an obscure and compliant housewife into an independent and self-assured writer and activist. Moreover, Gilman's allusions to "Reason," and her emphatic identification with the "King," recall Whitman's verse on a number of levels. First, the incredible empowering force of Reason is suggested by the speaker's "thirst for [spiritual] advancement"; she explicitly craves and yearns for a higher knowledge. Second, her declaration that she is King suggests the powerful presence of the God within, which evokes Whitman's line from Section 48, "nothing, not God, is greater to one than one's self" ( $L G, 86)$. Finally, her use of the male gender referential, "King," may seem somewhat curious until we realize that Whitman, too, in "Song of Myself" and in numerous other poems, not only asserts the equality of gender, but often adopts a feminine persona, celebrates womanhood, and uses gender references interchangeably: "I am the poet of the woman the same as the man," Whitman writes in Section 21 of "Song of Myself" ( $L G$, 48).

In addition to finding genuine inspiration in Whitman's poems, Gilman occasionally satirized his verses with a twist of feminist irony. In his poem "The Dalliance of Eagles," for example, Whitman describes the beauty of the intricate mating ritual of two eagles in flight. Gilman, however, produced a feminist version of the poem, replacing the sensual beauty of Whitman's imagery with a rather facetious verse titled "Wedded Bliss." It reads: 
"O come and be my mate!" said the Eagle to the Hen;

I love to soar, but then

I want my mate to rest

Forever in the nest!"

Said the hen, "I cannot fly,

I have no wish to try,

But I joy to see my mate careering through the sky!"

They wed, and cried, "Ah, this is Love, my own!"

And the Hen sat, the Eagle soared, alone. ${ }^{11}$

The disparity between the sexes was, of course, a theme upon which Gilman focused in much of her writing-in her poems, in her short stories and novels, and in countless essays. Her tireless campaign for equal rights was often overshadowed by the reality of female subjugation, and the poem "Wedded Bliss" became another means of expressing her sometimes sardonic views on the issue of subordination in marriage. At other times, Gilman's writing offered a bit of comic relief from the intensity of her work as a social reformer. On May 13, 1897, for example, Gilman noted in her diary that she was preparing the third edition of her poetry volume for republication. "Am feeling rather dull," she wrote. "Read lots of poems to Mrs. Dow as she sews." The next day, perhaps as a remedy for her doldrums, Gilman wrote a satirical poem titled "Their Grass!" an allusion to the scorched California landscape. In her diary, Gilman reported laughing "hilariously" over the outcome of that day's poetic endeavors. ${ }^{12}$ Targeted at tourists who were disappointed to find that the parched California lawns compared unfavorably to their lush "wide acres of soft grass" back home, the poem gently mocks the disillusioned travelers by humorously alluding to Leaves of Grass. Gilman's speaker protests to the reader, "You'd think Walt Whitman was all they [had] read!" (ITOW, 93).

The most significant similarity between Whitman and Gilman was their commonly shared conviction concerning women's "place" in society. Both believed that women needed to expand their roles, to grow intellectually, to assume control over their lives. As Whitman asserted to his friend and literary executor, Horace Traubel, "Leaves of Grass is essentially a woman's book: the women do not know it, but every now and then a woman shows that she knows it: it speaks out the necessities, its cry is the cry of the right and wrong of the woman sex . . . of the feminine: speaks out loud: warns, encourages, persuades, points the way." "Since Gilman would spend a lifetime attempting to "point the way," she found in Whitman a spiritual soul mate. Moreover, his assertion in "Democratic Vistas," that women should become as "great . . . as man, in all departments," that they are "capable of being so, soon as they realize it, and can bring themselves to ... launch forth, as men do, amid real, independent, stormy life," 14 is at the heart of all of Gilman's polemics lamenting the condition of women in the late 
nineteenth century. In addition to her book-length works on the subject, such as Women and Economics and The Home, many of Gilman's poems address the socially imposed limitations placed on women and answer Whitman's call for human beings-male and female-to heed the "lesson of Nature" and to allow the "self, according to its own central idea and purpose" to awaken, to grow, and to expand. ( $D V$, 394).

Yet, despite the common vision shared by the two poets, there were significant points of departure both in style and in subject. Gilman was a considerably more conservative poet: her verse rarely addressed issues pertaining to sexuality, for example; such subjects apparently seemed to Gilman to be the province of the male poet, particularly in light of Walter Stetson's vehement opposition to Whitman's sexual imagery. Moreover, her poetry, on the whole, was more consciously didactic than Whitman's. And while Gilman did experiment with free verse, the bulk of her poetry was confined to more conventional forms, most likely because she was attempting to impart particular social messages in a manner that would be easily comprehensible to the majority of her readers.

One point of departure between the two poets is in their view of democracy. While Gilman shared Whitman's idealized vision of a democratic world, her real-life experiences as a woman struggling for equality in a patriarchal society often caused her to create verses that were cynical, bitter, or satirical in their depiction of the reality of a woman's life. In a poem called "The Commonplace" (ITOW, 4-7) written in 1897, Gilman seems to be consciously responding to Whitman's poem by the same name, which first appeared in 1891 ( $L G, 553-554)$. Whitman's version of "The Commonplace" celebrates the "democratic wisdom" that is derived from the human's immersion in the experiences of life, from "Your farm-your work, trade, occupation." Whitman clearly advocates the attainment of wisdom through experience: "The commonplace I sing; . . . I The open air I sing, freedom, toleration, / (Take here the mainest lesson-less from books-less from the schools,) / The common day and night - the common earth and waters, ... / The democratic wisdom underneath, like solid ground for all." Gilman's version of "The Commonplace," however, depicts the reality of female subjugation that necessarily limited the degree of "democratic wisdom" that women could attain. Her poem focuses on the dull monotony that characterized the lives of the majority of women who succumbed to pressure to assume socially prescribed roles:

Life is so weary commonplace! Too fair

Were those young visions of the poet and seer. . . .

Life is so tedious, slow, and flat,

And every day alike in everywhere! 
Life comes. Life-

Bearing within its wisdom, work, and strife. . . .

To do, to strive, to know, and with the knowing

To find life's widest purpose in our growing. . . .

Life is so dreary commonplace. We bear

One dull yoke, in the country or the town.

We're born, grow up, marry, and settle down.

I used to think-but then a man must live!

The Fates dole out the weary years they give,

And every day alike in everywhere.

While "those young visions of the poet and seer" could apply to either Whitman's view of democracy or to Gilman's own youthful idealization of the potential for gender equality, the point that the speaker emphasizes in this poem is the elusive nature of fulfillment and happiness for women, who are "born, grow up, marry, and settle down." Gilman's women must subjugate their own needs and sacrifice their own desires in order that their men might "live." In effect, the female speaker in Gilman's "The Commonplace" comes to realize that "those young visions" of a fulfilling married life were grounded in naiveté and illusion: "I used to think-but then a man must live!" Men "live" in much of Gilman's literature, while women suppress their inclination to "think" and, as a result, simply exist. Democratic wisdom, then, as Whitman describes it, is clearly a male privilege.

Likewise, the departures in the two poets' perceptions of gender empowerment are seen in highly metaphorical poems as well. In Whitman's "The Ship Starting," for example, the poet romanticizes the sea through the use of sensuous, evocative, and even erotic female imagery $(L G, 12)$. The sea is described as "unbounded," and its "emulous waves press forward" surrounding the ship "with shining curving motions and foam." The female ocean is receptive, caressing, nurturing; on "its breast," a ship sets sail. In Gilman's poem, "The Ship," however, the vessel becomes a metaphor for the woman, broken and drowned in a tempestuous sea. Romanticized in the first stanza of this poem, the tide quickly turns, and the ship-as-woman lies in wreckage in the final stanza. Gilman suggests in this poem that gender equality is not as easily accessible as Whitman's verse makes it seem; rather, it is elusive and illusory:

The sunlight is mine! And the sea!

And the four wild winds that blow!

The winds of heaven that whistle free-

They are but slaves to carry me

Wherever I choose to go!

Fire for a power inside!

Air for a pathway free! 
I traverse the earth in conquest wide;

The sea is my servant! The sea is my bride!

And the elements wait on me!

In dull green light, down-filtered sick and slow

Through miles of heavy water overhead,

With miles of heavy water yet below,

A ship lies, dead.

Shapeless and broken, swayed from side to side,

The helpless driftwood of an unknown tide. (ITOW, 67)

While the initially accommodating "elements" facilitate the voyage of the vessel through the vast oceanic waters, the abrupt and violent destruction of the ship suggests the likely experience of the latenineteenth-century woman who dared to seek freedom, democracy, and equality in an oppressive and inhospitable society.

The point here is that Gilman obviously appreciated Whitman's acknowledgment of female oppression and his emphasis on gender equality; her view of democracy and equality, however, was shaped by actual experience, while Whitman's depiction, although undeniably sympathetic, was also largely idealized. At the same time, although his depictions of women were occasionally questionable (such as in his poem, "A Woman Waits for Me," which contains an apparent rape fantasy), Gilman found enough value in his work so that controversial passages did not eclipse her appreciation of his art. Their common vision was far greater than their points of departure. Gilman undoubtedly applauded, for example, Whitman's depiction of womens' strengths in the fifth stanza of "A Woman Waits for Me," where he writes:

They are not one jot less than I am,

They are tann'd in the face by shining suns and blowing winds,

Their flesh has the old divine suppleness and strength,

They know how to swim, row, ride, wrestle, shoot, run, strike, retreat, advance, resist, defend themselves,

They are ultimate in their own right-they are calm, clear, well-possess'd of themselves. ( $L G, 102)$

Interestingly, one theme addressed by both poets is the plight of prostitutes. Whitman defended the practice of prostitution, "advocating a system of licensing prostitutes" and mandatory medical examinations to keep them healthy, ${ }^{15}$ while Gilman sympathetically characterized prostitutes in a number of her poems, including "One Girl of Many," "Unmentionable," and "The Lesson of Death." Whitman's poetic representations of prostitution in such poems as "The City Dead-House," "Native Moments," and "To A Common Prostitute" recognized that the healthy sexual expression of the woman was compromised when she 
was forced to sell her body for profit. Gilman, too, saw an analogy between women who were "exploited for the pleasure of men, not only in ... prostitution, but also in their helpless subservience in marriage." ${ }^{16}$ Both Whitman and Gilman acknowledged the surrender of legal, economic, and political equality that prostitution entailed.

The concept of "perfect motherhood" is another point at which Gilman and Whitman's ideologies intersect. While Whitman calls for both "the perfect equality of women, and of a grand and powerful motherhood," Gilman gradually evolved a theory which eventually became "The New Motherhood," a treatise on which many of her subsequent socio-economic theories were based. Her theory of The New Motherhood advocated "the fullest development of the woman, in all her powers, that she may be better qualified for her [maternal] duties."17 Whitman, too, supported "the fullest development" of women, so that they could be rescued out of the "incredible webs of silliness, millinery, and every kind of dyspeptic depletion" in order to become part of "a race of perfect mothers" $(D V, 372)$. Although Whitman has been criticized for perpetuating yet another form of female oppression through his celebration of motherhood, it is likely that Gilman recognized that his views were not, in fact, grounded in chauvinism, but that he simply acknowledged the unique reproductive capability of the female to give birth. His tender portrayal of motherhood in "Mother and Babe," for example, and his observation in "Unfolded Out of the Folds" that "[a] man is a great thing upon the earth and through eternity, but every jot of the greatness of man is unfolded out of woman" $(L G, 391)$ suggest his reverence of woman is indeed related to her potential to create new life. Clearly, however, Whitman did not advocate motherhood as a full-time endeavor. He understood well, in fact, that woman was multi-dimensional-that her "body [was] indeed political, blending the erotic with the maternal in a challenge to the prevailing [assumptions]" (Winter, 208).

As contemporary readers, it is heartening to note that Charlotte Stetson, the once-obedient bride-to-be, transformed herself into a strong and independent woman who would finally not allow her husband, or any man, to censor her choice of reading material. Her frequent diary entries, alluding to her enjoyment of Whitman's verse, suggest that her appreciation of the poet was somehow greater precisely because of her realization of what she nearly lost - the inspiration of Whitman's creative genius -in attempting to appease her fiancé. As fate would have it, late in 1897, a few years after her divorce from Walter Stetson, on the day that they accepted her manuscript for her landmark feminist treatise Women and Economics, her publishers, Small, Maynard \& Co. bestowed upon her a small but cherished gift: a brand new copy of Leaves of Grass. Her diary records the joy she experienced in reading it all over 
again. A couple of weeks after receiving Leaves of Grass, the diary mentions that she had a splendid time reading Whitman to her future second husband, Houghton Gilman, who also enjoyed it immensely. ${ }^{18}$ Years later, in 1919, Charlotte Gilman served as a featured speaker at the final meeting of the Walt Whitman Society of New York. ${ }^{19}$

Whitman's influence on Charlotte Gilman lasted a lifetime. As late as 1933, two years before her death, Gilman still lauded Whitman as one of "our . . . greatest Americans." 20 In 1934, as she began to plan her suicide to escape the indignities of a slow and painful death from breast cancer, Charlotte Perkins Gilman wrote to various friends to say goodbye and to offer them comfort. In some of her letters, she paraphrased Section 48 of "Song of Myself," writing, "No words can say how utterly at peace I am about God and about death." ${ }^{21}$ Even at the end of a very long and productive life, Gilman still found inspiration in the words of the poet she most admired.

\section{State University of New York, College at Cortland}

\section{NOTES}

1 Diary for 1883, Charlotte Perkins Gilman Papers, Schlesinger Library, Radcliffe College, Cambridge, MA. Hereafter, CPG Papers.

2 Mary A. Hill, Endure: The Diaries of Charles Walter Stetson (Philadelphia: Temple University Press, 1985), 201. Hereafter, Endure.

3 Folder 165, CPG Papers.

4 Karl Shapiro, "The First White Aboriginal," Start With The Sun: Studies in Whitman Tradition (University of Nebraska Press, 1960), 68.

5 Mabel McCoy Irwin, Whitman, the Poet-Liberator of Woman (New York, 1905), 21, 24.

6 Charlotte Perkins Gilman, rev. of Women and Labor, by Olive Schreiner, Forerunner 2 (July 1911), 197.

7 Gary Scharnhorst was the first to comment on the relationship between Gilman's verse and Whitman's in his monograph, Charlotte Perkins Gilman (Boston: Twayne, 1985), 40-42. The idea of the connection between Gilman's celebration of the self and Whitman's is his.

8 Charlotte Perkins Gilman, In This Our World, 3rd edition (Boston: Small, Maynard \& Co., 1908), 1-2. In This Our World was first published in 1893 in Oakland by McCombs \& Vaughn. The second edition was published in San Francisco in 1895 by the Press of James H. Berry, and the third, enlarged edition appeared in 1898 from Small, Maynard \& Co. of Boston. Subsequent printings of the third edition were published by Small, Maynard, \& Co. as follows: the second printing appeared in 1899, the third printing in 1908 , the fourth in 1913, and the fifth in 1914. All subsequent page numbers refer to the third printing of the third edition. Hereafter, ITOW.

9 Diary for 1884, CPG Papers. 
10 Leaves of Grass, Comprehensive Reader's Edition, ed. Harold W. Blodgett and Sculley Bradley (New York: New York University Press, 1965), 35. Hereafter, LG.

11 ITOW, 157-158. Gary Scharnhorst points out Gilman's satirical version of "The Dalliance of Eagles," in Charlotte Perkins Gilman, 41-42.

12 Diary for 1897, CPG Papers.

13 Whitman, in Traubel's With Walt Whitman in Camden, quoted in Betsy Erkkila's Whitman the Political Poet (New York: Oxford University Press, 1989), 308.

14 Walt Whitman, "Democratic Vistas," in Prose Works 1892, ed. Floyd Stovall (New York: New York University Press, 1964), 2:389. Hereafter, DV.

15 Kate H. Winter, "Whitman and the Women: The Poet as Feminist" in Long Island Historical Fournal 4 (Spring 1992), 209.

16 Charlotte Perkins Gilman, "Feminism" (in typescript), CPG Papers, Folder 175.

17 Charlotte Perkins Gilman, “The New Motherhood," Forerunner 1 (December 1910), 17.

18 Diary for 1897.

19 Joann P. Kreig, "Charlotte Perkins Gilman and the Whitman Connection." Walt Whitman Quarterly Review 1 (March 1984), 21-25.

20 Quoted in Scharnhorst, 126.

21 Quoted in Scharnhorst, 117. 